\title{
Article \\ Management of the First Feeding of Dorada Brycon sinuensis with Two Species of Cladocerans
}

\author{
César Jiménez-Velásquez ${ }^{1}$, Victor Atencio-Garcia ${ }^{2}{ }^{\circ}$, Julia Eva Ayazo-Genes ${ }^{1}$, José Espinosa-Araujo ${ }^{2}$ \\ and Martha Prieto-Guevara 2,*(D) \\ 1 Fish Culture Research Institute CINPIC, University of Córdoba, Montería Cr 6 77-305, Colombia; \\ cesarjimenez@correo.unicordoba.edu.co (C.J.-V.); juliaayazog@correo.unicordoba.edu.co (J.E.A.-G.) \\ 2 Faculty of Veterinary Medicine and Animal Husbandry, Department of Aquaculture Sciences, \\ Fish Culture Research Institute, University of Córdoba, Montería Cr 6 77-305, Colombia; \\ vatencio@correo.unicordoba.edu.co (V.A.-G.); jaespinosaaraujo@correo.unicordoba.edu.co (J.E.-A.) \\ * Correspondence: mprieto@correo.unicordoba.edu.co
}

check for updates

Citation: Jiménez-Velásquez, C.; Atencio-Garcia, V.; Ayazo-Genes, J.E.; Espinosa-Araujo, J.; Prieto-Guevara, M. Management of the First Feeding of Dorada Brycon sinuensis with Two Species of Cladocerans. Appl. Sci. 2021, 11, 9379. https://doi.org/ 10.3390/app11209379

Academic Editors: Tiago Verdelhos and Ana Cristina Rocha

Received: 20 August 2021

Accepted: 4 October 2021

Published: 9 October 2021

Publisher's Note: MDPI stays neutral with regard to jurisdictional claims in published maps and institutional affiliations.

Copyright: (c) 2021 by the authors. Licensee MDPI, Basel, Switzerland. This article is an open access article distributed under the terms and conditions of the Creative Commons Attribution (CC BY) license (https:/ / creativecommons.org/licenses/by/ $4.0 /)$.

\begin{abstract}
The management of the first feeding is a critical stage in the viability of the larvae and fingerling rearing. So far, the first feeding of the bryconids record the best results when fed with forage larvae; thus, the aim was to evaluate two species of cladocerans as live prey in the first feeding of dorada Brycon sinuensis and to evaluate their effects on the control of cannibalism. Larvae $(1.2 \pm 0.15 \mathrm{mg}$ and $5.9 \pm 0.4 \mathrm{~mm}$ initial weight and total length) were fed Moina minuta $(\mathrm{Mm})$, Macrothrix elegans (Me) or a mixture (50:50) of cladocerans (Mix) at a rate of 20 prey $\mathrm{mL}^{-1}$, once for $24 \mathrm{~h}$. Another dorada larvae group were fed newly hatched larvae of Piaractus brachypomus $(4.5 \pm 0.9 \mathrm{~mm})$ as forage larvae $\left(\mathrm{F}_{\mathrm{L}}\right)$ in a ratio of 2:1 (prey:predator). The larvae were stocked to $50 \mathrm{~L}^{-1}$ in aquaria with $5 \mathrm{~L}$ of useful volume (12 per treatment). The growth, survival, stress resistance, cannibalism mortality, and the number of prey in the gut contents were analyzed. Dorada larvae fed $\mathrm{F}_{\mathrm{L}}$ showed higher growth, but those fed Mm showed the highest survival rate $(76.1 \pm 6.6 \%)$ and the lowest cannibalism mortality $(16.8 \pm 3.7 \%)(p<0.05)$. The use of the cladocerans allowed high survival and stress resistance $(95.3 \pm 2.4 \%)$, and $M$. minuta proved to be a suitable prey for cannibalism control in the management of the first feeding of dorada larvae.
\end{abstract}

Keywords: cannibalism; live food; larval feeding; fish larvae

\section{Introduction}

Dorada Brycon sinuensis is an endemic species of fish of the Sinú River Basin (Córdoba, Colombia), threatened by the deterioration of its natural environment [1]. Like other bryconids, this species presents characteristics desirable for fish farming, including rapid growth, acceptance of artificial diets, easy adaptation to captivity, resistance to handling, and omnivorous diet [2]. The management of first feeding is done for only $24 \mathrm{~h}$ because this is the critical period of intensive larviculture of this species. This technique allows the larvae to be viable for the next stages of the production process and reduces cannibalism during this critical stage $[2,3]$. The bryconids' life cycle is characterized by a fast embryonic stage (12-14 $\mathrm{h}$ to $26-28^{\circ} \mathrm{C}$ ); the larvae begin the exogenous feeding between 22 and $24 \mathrm{~h}$ after hatching (hae); management of first feeding is short $(24 \mathrm{~h})$. During this phase the maximum mouth opening is estimated at 20-25\% of total length (5 to $6 \mathrm{~mm}$ ); there is a short larval period (7 days); and like other bryconids, Brycon sinuensis shows strong cannibalism at the beginning of the exogenous feeding [2,4-8]. This behavior causes low survival rates and heterogeneity in larval size [2,7,9]. To reduce cannibalism in bryconids, larvae of another fish species (forage larvae) are often supplied as an initial live feed to increase survival and control cannibal behavior in this stage of larviculture. The rearing of fingerlings of dorada has advanced in the use of forage larvae with the first feeding management [2]; however, this method increases the production costs of fingerlings, so it is 
necessary to look for alternatives with zootechnical potential as an initial live food source for the production of fingerlings without the use of forage larvae.

A possible alternative for managing bryconids' first feeding and cannibalism control is the use of cladocerans selected and grown under controlled conditions. The potential of cladocerans as a biotech food alternative for the performance of fish of aquaculture interest is well known. During rearing, dorada culture (nearly 15 days) shows selectivity for zooplankton groups, copepods, and ostracods [10]. Still, no studies evaluated the use of cladocerans in the first feeding of dorada larvae.

The biochemical composition of cladocerans is important for fish larvae because it contains most of the nutritional requirements for the survival and adequate development of the larvae [11,12]. Furthermore, due to their content of essential fatty acids [13-17] and high levels of excellent quality protein [18], cladocerans are an essential source of the vitamins, minerals [19], and enzymes necessary for larval growth and survival [20-22].

Most fish larvae require planktonic organisms as their first feed and record better growth and survival rates when fed these organisms rather than artificial diets [5,10,23-26]. Several factors explain these results: the structure and digestibility of the protein, presence of exogenous enzymes, chemical stimuli, adequate size, and slow movements of the prey that facilitate its ingestion and digestion, characteristics that meet the requirements of the larva [27]. Another feature that justifies the use of cladocerans in fish larviculture is the predatory visual stimulus provided to larvae due to the natural motility of the plankton [28].

Despite the lack of information on the management of the first feeding of B. sinuensis with selected cladocerans, the described characteristics make this zooplankton an interesting option to be evaluated as prey in larviculture. As stated in the 2021 Shanghai Declaration: Aquaculture for food and sustainable development, diversification is presented as an option or key to sustainable development. The diversification of aquaculture production implies new investment alternatives for both the industrial and artisanal sectors, and the first step is to expand the variety of species offered by aquaculture.

This study may support this strategic priority and help the sustainability of Colombian aquaculture and reduce non-native species. Specifically, the aquaculture of the bryconids will be strengthened through the management of larviculture, which contributes to the availability of seed for the next stage in the production process, offering natural prey recognized by the species, in this case, the cladocerans. Simultaneously, it contributes to sustainability, avoiding dependence on expensive inputs such as Artemia and eutrophication of the effluent due to the death of unnatural prey used in the process, thus reducing the production of nitrogen compounds. Consequently, the process is more environmentally friendly. Therefore, the study aimed to assess two species of cladocerans as prey during the onset of exogenous feeding of dorada and to evaluate their effects on the control of cannibalism.

\section{Materials and Methods}

The study was conducted at the Fisheries Research Institute of the University of Córdoba (CINPIC), located in Montería (Colombia). Cladocerans Moina minuta (length $690.2 \pm 10.2 \mu \mathrm{m}$ and width $416.1 \pm 11.7 \mu \mathrm{m}$ ) and Macrothrix elegans (length $492.9 \pm 3.0 \mu \mathrm{m}$ and width $293.7 \pm 2.7 \mu \mathrm{m}$ ) were isolated following the methodology of Prieto-Guevara, et al. [29] from zooplankton samples collected in the CINPIC ponds with a conical net of $250 \mu \mathrm{m}$ of mesh. Identification of the cladocerans was carried out using the taxonomic keys described by Sars [30]. The initial strains and inoculum, which were maintained in the Living Food Laboratory of the CINPIC, were placed in 200-mL glass bottles, in water filtered through a 20- $\mu \mathrm{m}$ mesh, kept in a photoperiod 10:14 h (light:darkness) and 30\% of the water volume was renewed every $48 \mathrm{~h}$ to remove organic matter from the bottom. Daily feeding was based on a mixture of the microalgae Ankistrodesmus sp. and Scenedesmus sp., at a concentration of $4 \times 10^{5}$ cell $\mathrm{mL}^{-1}$, determined by cell counting in a Neubauer chamber. The increase in 
the biomass of the cladocerans was obtained using successive inoculations and the serial volume method [29].

The larvae of dorada and Piaractus brachypomus were obtained by reproduction induced with carp pituitary extract ( $5 \mathrm{mg} / \mathrm{kg}$ of live weight), applied in two doses of $20 \%$ and $80 \%$ at an interval of $12 \mathrm{~h}$ [2]. Incubation of the fertilized eggs was performed in 60-L cylindrical-conical upflow incubators; after hatching (70\%), the dorada larvae were transferred to circular fiberglass tanks with a useful volume of $1000 \mathrm{~L}$. At the beginning of exogenous feeding (22 hae), 4000 dorada larvae of were distributed in 16 aquaria of $5 \mathrm{~L}$ of useful volume, at a density of 50 larvae $\mathrm{L}^{-1}$. In addition, a sample of 100 larvae was fixed in $1 \%$ buffered formalin to measure the initial weight $(1.2 \pm 0.15 \mathrm{mg})$ and total length $(5.9 \pm 0.4 \mathrm{~mm})$. The larvae were feed treatments, with four replicates each, M. minuta $(\mathrm{Mm})$, M. elegans (Me), and a mixture of these cladocerans (50:50) (Mix). The cladocerans were offered at the rate of 20 prey $\mathrm{mL}^{-1}$, once for $24 \mathrm{~h}$, and another group was fed freshly hatched larvae of Piaractus brachypomus (FL) $(4.5 \pm 0.9 \mathrm{~mm})$ in a 2:1 ratio (prey:predator) [2]. This group was considered the control treatment. The proximal composition of the different prey offered to the dorada larvae was analyzed according to the AOAC official methods [31].

After $24 \mathrm{~h}$, the survival, natural mortality, cannibalism mortality, stress resistance test, growth, and gut contents were evaluated. The survival (S) was assessed using the formula $\mathrm{S}=\left(\mathrm{N}_{\mathrm{F}} / \mathrm{N}_{\mathrm{O}}\right) \times 100$, where $\mathrm{N}_{\mathrm{F}}$ was the final number of live larvae, and $\mathrm{N}_{\mathrm{O}}$ was the initial number of larvae. Larval quality was evaluated by stress resistance test $\left(S_{R}\right)$, which was considered an indicator of the management; from each experimental unit, the larvae were removed $(n=10)$ with a mesh of $400 \mu \mathrm{m}$ and maintained for six minutes in conditions of severe hypoxia; then they were returned to the experimental units, and after $15 \mathrm{~min}$ the larvae that survived the test were counted. The $S_{R}$ was assessed using the formula $\mathrm{S}_{\mathrm{R}}=\mathrm{N}_{\mathrm{AL}} / \mathrm{N}_{\mathrm{T}} \times 100$, where $\mathrm{N}_{\mathrm{AL}}$ was the number of alive larvae, and $\mathrm{N}_{\mathrm{T}}$ was the total number of larvae treated to the severe hypoxia conditions [2].

The mortality for cannibalistic behavior $\left(\mathrm{C}_{\mathrm{M}}\right)$ was assessed by counting the dead larvae that showed mutilation or bite under a inverted microscope (Carl Zeiss, Stemi 2000-C, Jena-Germany). It was estimated using the formula $C_{M}=$ (cannibalized larvae/total initial larvae $\times 100$. The natural mortality $\left(\mathrm{N}_{\mathrm{M}}\right)$ was calculated by counting the dead larvae that did not show signs of mutilation or bite, and was assessed using the formula $N_{M}=$ (total of dead larvae - dead larvae by cannibalism)/total initial larvae $\times 100$ [2]. In addition, the stomach contents $(n=15 /$ replicate) were assessed to verified cladoceran species ingested (microdissection) and cannibalism with an inverted microscope (Carl Zeiss, Stemi 2000-C, Jena, Germany).

In a sample of dorada larvae $(n=20)$ fixed in $1 \%$ buffered formalin, the total length of larvae was measured using a inverted microscope Stemi 2000-C (Carl Zeiss, Jena, Germany) and an image analyzer Axiovision 4 (Carl Zeiss, Gottingen, Germany). The fresh weight (the excess moisture was removed with blotting paper) was recorded using an analytical balance Adventurer (Ohauss, Shanghai, China, $\pm 0.001 \mathrm{~g}$ ). The length gain $\left(\mathrm{L}_{\mathrm{G}}\right)$, weight gain $\left(W_{G}\right)$, and the specific rate of growth $(G)$ were assessed using the formulas [32]:

$\mathrm{L}_{\mathrm{G}}=\mathrm{L}_{\mathrm{F}}-\mathrm{L}_{\mathrm{O}}$, where $\mathrm{L}_{\mathrm{F}}$ and Lo were, respectively, the total final and initial length of the larvae;

$\mathrm{G}_{\mathrm{W}}=\mathrm{W}_{\mathrm{F}}-\mathrm{W}_{\mathrm{O}}$, where $\mathrm{W}_{\mathrm{F}}$ and $\mathrm{W}_{\mathrm{O}}$ correspond, respectively, to the final and initial weight of the larvae

$\mathrm{G}=\left[\mathrm{Ln}\left(\mathrm{W}_{\mathrm{F}} / \mathrm{W}_{\mathrm{O}}\right)\right] / \mathrm{T} \times 100$, where $\mathrm{T}$ correspond to the larviculture time (day) and $\mathrm{Ln}$ to the natural logarithm.

The quality of the water in the experimental units registered dissolved oxygen $\left(4.7 \pm 0.2 \mathrm{mg} \mathrm{L}^{-1}\right), \mathrm{pH}(8.0 \pm 0.4)$, temperature $\left(28.0 \pm 0.9^{\circ} \mathrm{C}\right), \mathrm{NH}_{3}\left(<0.12 \pm 0.06 \mathrm{mg} \mathrm{L}^{-1}\right)$, alkalinity $\left(36.1 \pm 1.9 \mathrm{mg} \mathrm{L}^{-1}\right)$, and total hardness $\left(64.6 \pm 1.9 \mathrm{mg} \mathrm{L}^{-1}\right)$; parameters within the normal range for the dorada larviculture [2].

The experimental design was completely randomized. All variables evaluated were first assessed to normality (Shapiro-Wilk test) and homogeneity of variance (Levene's test). Where necessary, arcsine-square root or logarithmic transformation was performed before 
analysis. One-way ANOVA was used to determine significant differences among treatments. Tukey's test was performed as the mean separation procedure. A statistical probability of $p<0.05$ was accepted as significant. All data are expressed as mean \pm standard deviation (SD). The analysis was performed with the statistical software $\mathrm{R}$ (version 3.0.2).

\section{Results}

The $S$ and $S_{R}$ of dorada larvae after $24 \mathrm{~h}$ are presented in Figure 1 . The highest $\mathrm{S}$ was recorded in larvae fed with $\mathrm{Mm}(76.1 \pm 6.6 \%)(p<0.05)$, but did not differ significantly $(p>0.05)$ from those fed with $\mathrm{F}_{\mathrm{L}}(64.0 \pm 13.5 \%)$ or with Mix $(64.1 \pm 8.5 \%)$. Survival of the dorada larvae $S_{R}$ test ranged between $92.5 \pm 5.0 \%(\mathrm{Me})$ and $95.3 \pm 2.4 \%(\mathrm{Mm})$, with no significant difference observed between the treatments $(p>0.05)$.

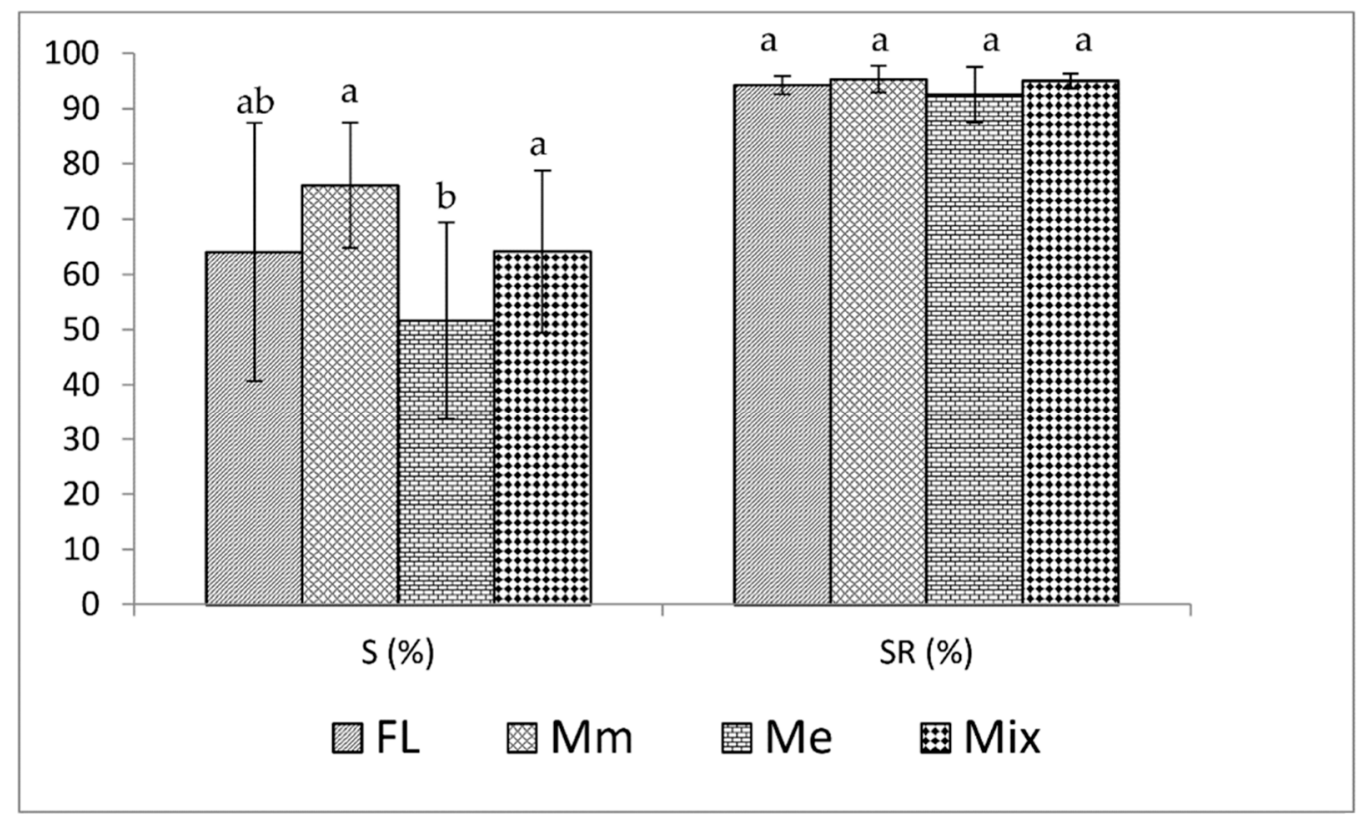

Figure 1. Survival $(S)$ and stress resistance $\left(S_{R}\right)$ of dorada Brycon sinuensis larvae fed different live prey. Different letters indicate a significant difference $(p<0.05)$. Forage larvae of Piaractus brachypomus $\left(\mathrm{F}_{\mathrm{L}}\right)$; Moina minuta $(\mathrm{Mm})$; Macrothrix elegans $(\mathrm{Me})$; mixture (50:50) of the Moina minuta and Macrothrix elegans (Mix).

Mortality due to cannibalism $\left(\mathrm{C}_{M}\right)$ and natural mortality $\left(\mathrm{N}_{\mathrm{M}}\right)$ at $24 \mathrm{~h}$ is presented in Figure 2. The highest $C_{M}$ in the dorada larvae was observed when feeding with $\mathrm{Me}$ $(39.6 \pm 6.7 \%)$ but without a significant difference $(p>0.05)$ from those fed $F_{L}(27.6 \pm 11.3 \%)$ and Mix $(29.7 \pm 6.6 \%)$. The $\mathrm{N}_{\mathrm{M}}$ of dorada larvae ranged between those fed with Mix $(6.2 \pm 2.3 \%)$ and those fed with Me $(8.8 \pm 6.4 \%)$ without a significant difference being observed between the treatments $(p>0.05)$.

The $\mathrm{W}_{\mathrm{G}}, \mathrm{L}_{\mathrm{G}}$ and $\mathrm{G}$ of the dorada larvae after $24 \mathrm{~h}$ are presented in Table 1, and proximate composition of prey is presented in Table 2. The $\mathrm{W}_{\mathrm{G}}$ of the dorada larvae fed the $\mathrm{F}_{\mathrm{L}}(1.5 \pm 0.4 \mathrm{mg})$ was significantly higher $(p<0.05)$, although it was not different from those fed $\mathrm{Mm}(0.5 \pm 0.1 \mathrm{mg})$. The $\mathrm{L}_{\mathrm{G}}$ of the dorada larvae fed the $\mathrm{F}_{\mathrm{L}}(1.6 \pm 0.1 \mathrm{~mm})$ was significantly higher $(p<0.05)$. However, this gain was not significantly different from that of the larvae fed the mixture of cladocerans $(1.0 \pm 0.3 \mathrm{~mm})$. The $\mathrm{G}$ of the dorada larvae fed the $\mathrm{F}_{\mathrm{L}}$ forage larvae $(3.2 \pm 0.4 \% / \mathrm{h})$ was significantly higher than those fed cladocerans $(p<0.05)$. 


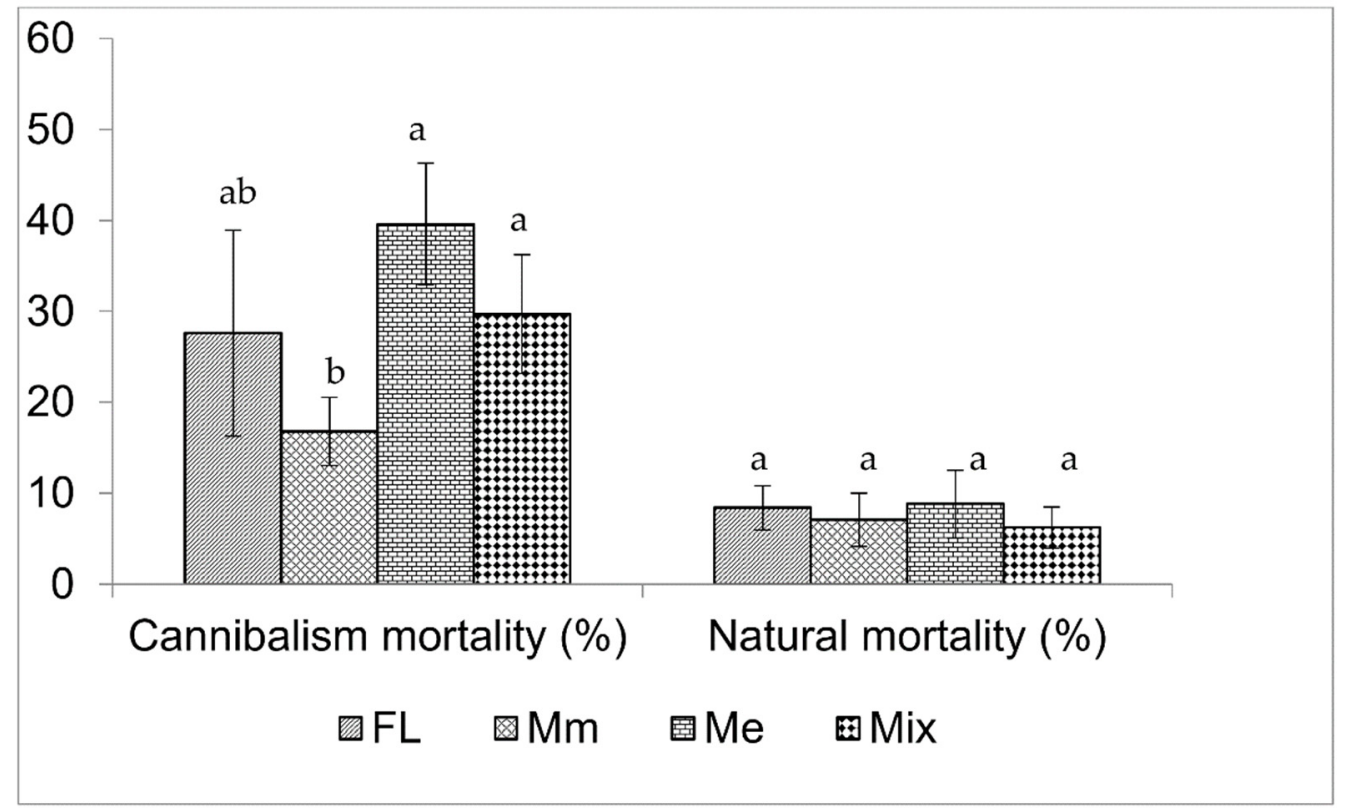

Figure 2. Mortality of larvae of dorada Brycon sinuensis fed different live prey. Different letters indicate significant difference $(p<0.05)$. Forage larvae of Piaractus brachypomus $\left(\mathrm{F}_{\mathrm{L}}\right)$; Moina minuta $(\mathrm{Mm})$; Macrothrix elegans (Me); mixture (50:50) of the Moina minuta and Macrothrix elegans (Mix).

Table 1. Weight gain $\left(\mathrm{W}_{\mathrm{G}}\right)$, length gain $\left(\mathrm{L}_{\mathrm{G}}\right)$, and specific growth rate $(\mathrm{G})$ of dorada Brycon sinuensis larvae after receiving different feeding prey for $24 \mathrm{~h}$. Forage larvae of Piaractus brachypomus $\left(\mathrm{F}_{\mathrm{L}}\right)$; Moina minuta (Mm); Macrothrix elegans (Me); mixture (50:50) of the Moina minuta and Macrothrix elegans (Mix).

\begin{tabular}{ccccc}
\hline Parameters & \multicolumn{5}{c}{ Treatments } \\
\hline & $\mathbf{F}_{\mathbf{L}}$ & $\mathbf{M m}$ & $\mathbf{M e}$ & Mix \\
\hline $\mathrm{W}_{\mathrm{G}}(\mathrm{mg})$ & $1.5 \pm 0.4 \mathrm{a}$ & $0.5 \pm 0.1 \mathrm{ab}$ & $0.3 \pm 0.1 \mathrm{~b}$ & $0.4 \pm 0.0 \mathrm{~b}$ \\
$\mathrm{~L}_{\mathrm{G}}(\mathrm{mm})$ & $1.6 \pm 0.1 \mathrm{a}$ & $0.9 \pm 0.2 \mathrm{~b}$ & $0.9 \pm 0.3 \mathrm{~b}$ & $1.0 \pm 0.3 \mathrm{ab}$ \\
$\mathrm{G}(\% / \mathrm{h})$ & $3.2 \pm 0.4 \mathrm{a}$ & $1.3 \pm 0.2 \mathrm{~b}$ & $0.8 \pm 0.2 \mathrm{~b}$ & $1.1 \pm 0.1 \mathrm{~b}$ \\
\hline
\end{tabular}

Different letters in the same row indicate a significant difference $(p<0.05)$.

Table 2. The proximate composition of prey: Forage larvae of Piaractus brachypomus $\left(\mathrm{F}_{\mathrm{L}}\right)$; Moina minuta (Mm); Macrothrix elegans (Me); mixture (50:50) of the Moina minuta and Macrothrix elegans (Mix).

\begin{tabular}{ccccc}
\hline & \multicolumn{4}{c}{ Treatments } \\
\hline Proximate Analysis & $\mathbf{F}_{\mathbf{L}}$ & $\mathbf{M m}$ & $\mathbf{M e}$ & Mix \\
\hline Crude protein & $52.3 \pm 0.1 \mathrm{e}$ & $57.9 \pm 0.1 \mathrm{c}$ & $80 \pm 0.1 \mathrm{a}$ & $60.7 \pm 0.1 \mathrm{~b}$ \\
Crude lipid & $66.9 \pm 0.1 \mathrm{a}$ & $32.1 \pm 0.1 \mathrm{e}$ & $37.4 \pm 0.1 \mathrm{~d}$ & $40.3 \pm 0.1 \mathrm{c}$ \\
Moisture & $77.4 \pm 0.1 \mathrm{~d}$ & $89.5 \pm 0.1 \mathrm{~b}$ & $89.6 \pm 0.1 \mathrm{~b}$ & $90.3 \pm 0.1 \mathrm{a}$ \\
Ash & $0.8 \pm 0.01 \mathrm{~b}$ & $0.6 \pm 0.01 \mathrm{c}$ & $0.6 \pm 0.01 \mathrm{c}$ & $0.8 \pm 0.01 \mathrm{~b}$ \\
\hline
\end{tabular}

Different letters in the same row indicate a significant difference $(p<0.05) .{ }^{*}$ Dry matter.

The prey present in the stomach contents of the dorada larvae after $24 \mathrm{~h}$ is illustrated in Figure 3. All prey supplied at the first feeding was found in the stomach contents of the dorada larvae. However, the lowest number of prey in the stomach contents was observed in the larvae fed on forage larvae $(0.8 \pm 0.0$ prey). In contrast, the highest number of prey was presented when fed Mm (3.7 \pm 0.0 prey). 


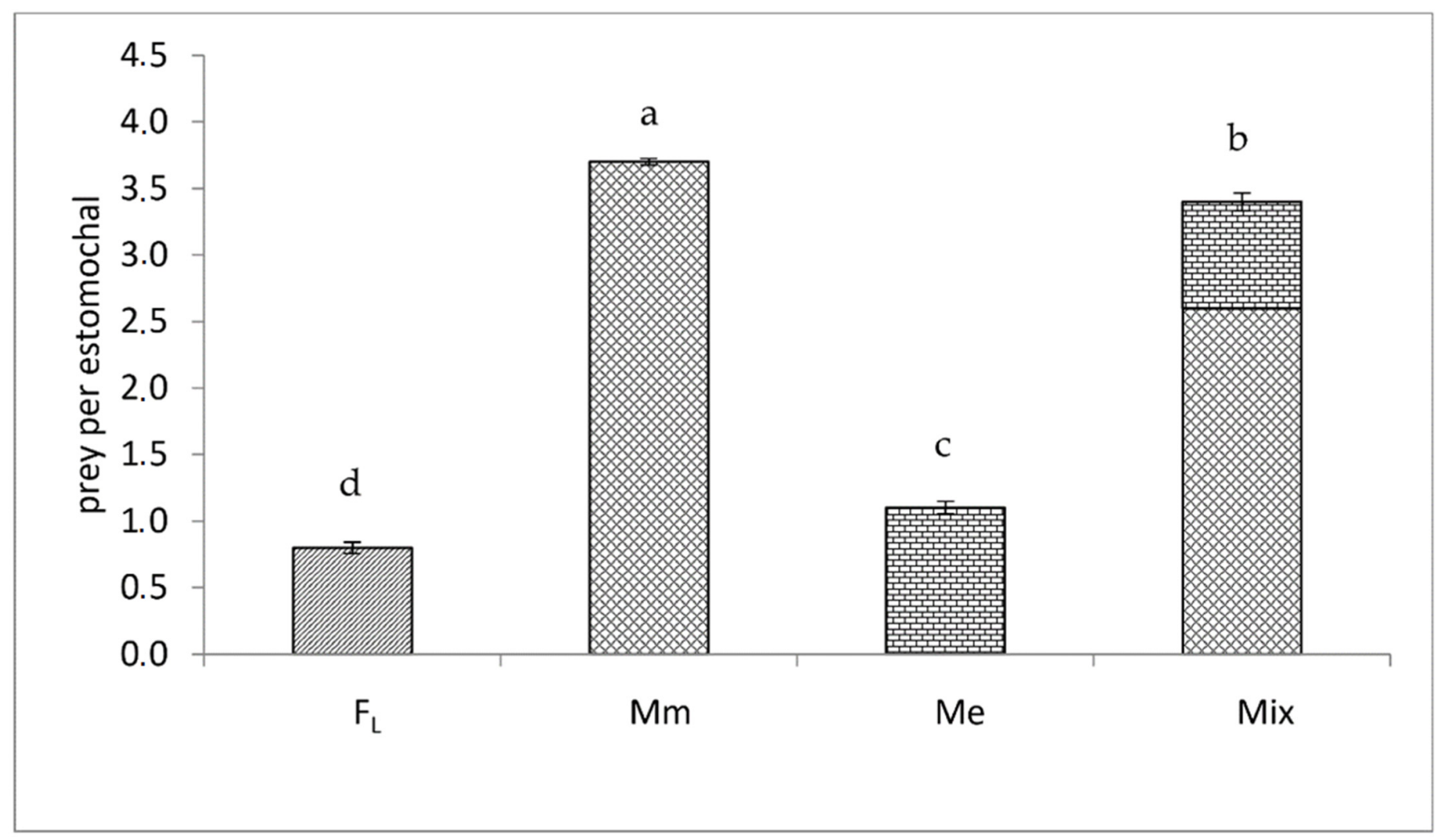

Figure 3. The number of prey in the stomach contents of dorada Brycon sinuensis fed different live prey. Different letters indicate a significant difference $(p<0.05)$. Forage larvae of Piaractus brachypomus $\left(\mathrm{F}_{\mathrm{L}}\right) ;$ Moina minuta $(\mathrm{Mm})$; Macrothrix elegans (Me); mixture (50:50) of the Moina minuta and Macrothrix elegans (Mix).

\section{Discussion}

Dorada larvae fed the cladoceran M. minuta at the beginning of exogenous feeding presented the highest survival in contrast with fed the M. elegans. The distribution and availability of the cladocerans in the water column could be suggested to explain this difference. M. minuta showed homogeneous distribution and sporadic movements in the entire water column making them more available and visible for capture by the dorada larvae. At the same time, M. elegans was distributed towards the aquarium walls (direct observation). The behavior registered of the cladoceran M. elegans coincides with observations in its natural environment. This cladoceran prefers substrates for its feeding and or as a protection mechanism against predators. Sousa and Elmoor-Loureiro [33] observed that the family Macrothricidae lives at the bottom or near vegetation and consider these cladocerans as phytophile organisms, which live mainly in association with roots and leaves of submerged macrophytes in the coastal zone. Diniz, et al. [34] studied the composition of the seasonal lakes of the semiarid regions of Pernambuco (Brazil). They registered that the cladocerans Macrothrix superaculeta and M. elegans were found to be associated with macrophytes. In the larviculture of the Perca eurasia the distribution of live food (Artemia nauplii and Barchionus plicatilis) was studied, and it was found that the feeding response was affected by the low density of live prey and its patterns of space utilization, which were very different from that of the larvae [35]. Some authors suggested that food availability and quality are the most critical factors that govern the establishment of hierarchies of dominance, growth, survival, and cannibalism, particularly in larvae of the genus Brycon $[2,4,36]$.

In the present study, adequate survivals $(64.0 \pm 13.5 \%)$ were recorded when fed with forage larvae at a ratio of 2:1. Atencio-García, et al. [2] found that the best survival in the management of the first feeding for dorada was recorded by offering two $(84.2 \%)$ and four (86.7\%) forage larvae (larvae of newly hatched Prochilodus magdalenae); in addition, a higher 
survival rate in Brycon amazonicus larvae (70.0\%) was reported after Piaractus brachypomus forage larvae (larvae newly hatched) were provided in a greater proportion (4:1) for $24 \mathrm{~h}$ [3]. In larvae fed the cladoceran mixture, survival did not show a significant difference from the other treatments, showing that although $M$. minuta only corresponds to half the prey density in this treatment (10 prey $\left.\mathrm{mL}^{-1}\right)$, that amount was sufficient to maintain survival at adequate values $(64.1 \pm 8.5 \%)$.

The dorada larvae presented similar results for the different treatments in the test of stress resistance. This result indicates that the prey offered an adequate nutritional quality to the larvae and allowed them to acquire high resistance against handling and transport. Prieto-Guevara, et al. [37] claimed that the stress resistance test allows the estimation of quality and viability of larvae according to the type of food used; thus, a best survival in this test indicates a better condition of the larva and therefore a better nutritional quality of the food offered in association with the management conditions. Atencio-García, et al. [2] stated that stress resistance due to anoxia conditions for $B$. sinuensis larvae is a valuable tool for determining the animal's physiological status before being sent to the nursery ponds. The responses to stress generally allow us to know how adaptive fish can be when faced with changes in their environment. These responses significantly impact survival during the early stages of fish life [38,39]. The results of stress resistance in the present study suggest that the larvae of $B$. sinuensis, fed the different live prey evaluated, were in good condition for handling and transfer to the next phase of rearing culture.

Mortality due to cannibalism was registered in all treatments but was higher when M. elegans $(39.6 \pm 6.7 \%)$ was offered. This result suggests that cannibalism in this treatment was related to the cladoceran distribution (M. elegans) in the experimental units, which reduced the feeding availability for dorada larvae in this treatment. Atencio-García, et al. [2] established that cannibalism in B. sinuensis is a feeding strategy associated with food availability. When the availability of prey decreases, the search for food increases; this implies an increase in energy expenditure [40]. Therefore, when fed Macrothrix elegans, the dorada larvae increased their cannibalism.

The adequate prey densities for the larvae is critical for increasing their intake. Different densities of zooplankton have been successfully used in other studies to reduce cannibalism and obtain satisfactory survival rates in the larval stage. In larvae with cannibalism similar to B. sinuensis, the following prey densities were found: 0.2 prey $\mathrm{mL}^{-1}$ (Artemia franciscana) [36], 0.5 pre $\mathrm{mL}^{-1}$ (Moina sp., Diaphanosoma sp., Artemia salina, Diaptomus) [9,41], 10 prey $\mathrm{mL}^{-1}$ (Diaptomus sp., Diaphanosoma sp., Moina sp. and Moinodaphnia sp.) [37], and 0.1 prey $\mathrm{mL}^{-1}$ (Brachionus plicatilis, Ceriodaphnia reticulata, Apocyclops dengizicus) [42]. The density of cladocerans used in this study $\left(20\right.$ prey $\left.\mathrm{mL}^{-1}\right)$ was higher than those reported in previous studies, suggesting that a homogeneous distribution of prey must accompany a high density to reduce cannibalism because it reduces the period of searching for prey and increases predator-prey encounters.

The natural mortality recorded in the present study was low and similar to the report of Atencio-García, et al. [2], who found natural mortality of less than $10 \%$ in the management of first feeding of dorada when fed forage larvae (Prochilodus magdalenae). Thus, the results of the present study suggest that cannibalism is the main cause of mortality in the management of the first feeding of dorada. In all treatments, mortality due to cannibalism was higher than natural mortality, but in larviculture worked with $M$. minuta this behavior was reduced to its minimum rate $(20 \%)$, which was less than half of the mortality observed with the other offered prey.

The highest LG, WG, and G values were recorded when the dorada larvae were fed with forage larvae ( $P$. brachypomus). This result is possible because larger prey allows greater energy efficiency for larvae than small prey. According to the optimal foraging theory, predators select prey that provide a high energy gain per unit of effort [40]. These authors claim that cannibalistic juveniles of Lates calcarifer choose smaller conspecifics when given a range of different sizes as prey. This behavior characterizes those cannibalistic predators that obtain high energy gain with the prey of similar or smaller size. Likewise, 
Atencio-García, et al. [3] found higher values of $L_{G}$ and $W_{G}$ for B. amazonicus when fed forage larvae ( $P$. brachypomus) compared to zooplankton, and they attributed this increase of growth to the lower energy expenditure in the capture of the forage larvae.

The appropriate size of the prey allows the predator to save more energy in catching and ingestion than a larger number of smaller organisms. Some authors consider that the density of prey defines growth and that the size of the food may be even more critical. A widely recorded pattern is the increase in growth rate and efficiency caused by increased prey size [43]. In some species of fish studied, bioenergetic alterations are the result of varying prey size or density that is predominantly driven by foraging activity, and when the prey is large and/or more abundant, predators tend to be less active [44,45], which leads to less energy spent on hunting and more growth [43].

Stomach contents of dorada fed different cladocerans as live prey reflect higher consumption of M. minuta (3.7 \pm 0.0 prey per stomach), followed by cladoceran mixture (3.4 \pm 0.1 prey per stomach), and finally by $M$. elegans ( $1.1 \pm 0.1$ prey per stomach). Notably, feeding with the mixture revealed greater food selectivity towards M. minuta $(2.6 \pm 0.0$ prey per stomach) over M. elegans ( $0.8 \pm 0.0$ prey per stomach), suggesting the importance of the distribution and availability and movements of prey. Accordingly, M. minuta presents desirable characteristics for the feeding of dorada larvae, such as size, shape, color, locomotion, and distribution.

Among cladocerans, the genus Moina is one of the most used in recent years for the first feeding of fish larvae. For example, the genus has been employed in the larvae of Pterophyllum scalare [46], Sorubim cuspicaudus [37], Leiopotherapon plumbeus [47], Oreochromis niloticus [48], and the crustacean Macrobrachium rosenbergii [49] because it features many of the desired characteristics for feeding aquatic organisms, thereby ensuring larval growth [50]: adequate size, slow movement, high availability, appearance, chemical stimulation, minimum nutritional requirements, and easy ingestion.

As previously described, the cladoceran M. elegans was distributed near the walls, with short shifts near the surface of the walls of the experimental units. This natural behavior gives this genus of cladocerans low visibility for consumption by the dorada larvae. Therefore, its potential as prey for dorada larvae is limited by its natural habit of being associated with aquatic substrates $[33,34]$. This behavior is considered an adaptive strategy of some zooplankton organisms to prevent predation. da Silva, et al. [5]) observed that in the stomach contents of hybrid catfish larvae (Pseudoplatystoma corruscans $x$ P. reticulatum) kept in a previously fertilized pond, the food item Macrothrix sp. (0.44\%) was the least consumed live prey, attributed mainly to them being organisms typical of benthic regions that may be captured only by larvae that exhibit this benthic behavior.

Therefore, M. minuta, presented with a homogeneous distribution in the water column, was a more visually attractive prey. Sampaio [27] found a higher selection of cladocerans in the different items offered to larvae Brycon amazonicus. This preference was attributed to a set of morphological characteristics that confer greater visibility to the larvae (size, shape, and pigmentation), and associated with this. In addition, their interrupted movements were an important factor that influenced food selection by visual predators. Botero [51] argued that size, shape, mobility, and contrast are the most important stimuli visual predators use in prey selection. In addition, the movement of the prey serves to differentiate the animate from the inanimate, which inclines the attention of the predator to a possible prey and increases the visibility of the same. On the other hand, [28] observed in larvae of Piaractus mesopotamicus that the type of stimulus coming from Artemia nauplii showed superior values of capture when they were compared with those stimuli coming from the inert diet; the authors indicated that the mobile prey induced tactile and visual responses and that the immobile prey escaped more easily from the attention of the predators.

Dorada, as well as other bryconids, can be considered a visual predator [8,52-54] because its eyes are well developed and pigmented; it has a wide mouth armed with pointed teeth at the beginning of exogenous feeding, as observed during the present study. 
In particular, for B. amazonicus, the rapid development of the eye was also visualized in the early larval stages, indicating the vision to be a fundamental ability in this period [55].

This study may support sustainable development and enhance fisheries' productivity through culture-based fisheries, and as appropriate, encouraging the production of endangered species and native species with potential for aquaculture. In the present study, it can be concluded that the cladoceran Moina minuta present desirable characteristics as live food, allowing high survival, adequate performance, and resistance to the stress of dorada larvae. Thus, is a viable prey for reducing cannibalism in managing the first feeding of dorada.

Author Contributions: Conceptualization, C.J.-V., M.P.-G. and V.A.-G.; methodology, C.J.-V., M.P.-G. and V.A.-G.; validation, C.J.-V. and V.A.-G.; formal analysis, J.E.A.-G.; investigation, C.J.-V.; resources, C.J.-V., M.P.-G. and V.A.-G.; data curation, J.E.A.-G.; writing-original draft preparation, C.J.-V.; writing-review and editing, M.P.-G. and V.A.-G.; visualization, J.E.-A.; supervision, J.E.-A.; project administration, J.E.-A.; funding acquisition, V.A.-G. All authors have read and agreed to the published version of the manuscript.

Funding: This research received no external funding.

Institutional Review Board Statement: The study was conducted according to the guidelines of the Declaration of Helsinki, and approved by the Ethics Committee of the Universidad de Córdoba (protocol code 001/18.02.2021 approved on 18 February 2021).

Data Availability Statement: Not applicable.

Conflicts of Interest: The authors declare no conflict of interest.

\section{References}

1. Mojica, J.I.E.; Usma Oviedo, J.U.E.; Alvarez León, R.E.; Lasso, C.A. Libro rojo de peces Dulceacuícolas de Colombia (2012); Instituto de Investigación de Recursos Biológicos, Alexander von Humboldt: Bogotá, Colombia, 2012.

2. Atencio-García, V.J.; Pertuz Buelvas, V.M.; Pérez Espitia, F.; Ortiz Mestra, R.; Carrasco, S.C.P. Manejo de la primera alimentación de dorada Brycon sinuensis ofreciendo larvas de bocachico Prochilodus magdalenae. Rev. Colomb. Cienc. Pecu. 2010, 23, 317-324.

3. Atencio-García, V.; Zaniboni-Filho, E.; Pardo-Carrasco, S.; Arias-Castellanos, A. Influência da primeira alimentação na larvicultura e alevinagem do yamú Brycon siebenthalae (Characidae). Acta Sci. Anim. Sci. 2003, 25, 61-72. [CrossRef]

4. Atencio-García, V.J.; Zaniboni Filho, E. El canibalismo en la larvicultura de peces. Rev. MVZ Córdoba 2006, 11, 9-19. [CrossRef]

5. da Silva, A.F.L.; Russo, M.R.; de Araújo Ramos, L.; Rocha, A.S. Feeding of larvae of the hybrid surubim Pseudoplatystoma sp. under two conditions of food management. Acta Sci. Biol. Sci. 2013, 35, 149-155. [CrossRef]

6. Ferraz, F.B.; Gomes, L.C. Social relationship as inducer of immunological and stress responses in matrinxã (Brycon amazonicus). Comp. Biochem. Physiol. Part A Mol. Integr. Physiol. 2009, 153, 293-296. [CrossRef] [PubMed]

7. Baras, E.; Lucas, M. Individual growth trajectories of sibling Brycon moorei raised in isolation since egg stage, and their relationship with aggressive behaviour. J. Fish Biol. 2010, 77, 985-997. [CrossRef] [PubMed]

8. de Souza, E.C.M.; da Silva, J.P.; Villacorta-Correa, M.A.; Carvalho, T.B. Aggressiveness and locomotion activity related to hatching time in Matrinxã, Brycon amazonicus (Spix and Agassiz, 1829). Appl. Anim. Behav. Sci. 2014, 157, 146-151. [CrossRef]

9. Marciales Caro, L.J.; DíazOlarte, J.J.; Medina Robles, V.M.; Cruz Casallas, P.E. Evaluación del crecimiento y sobrevivencia de larvas de bagre rayado Pseudoplatystoma fasciatum (Linneaus, 1766) alimentadas con alimento vivo natural y enriquecido con ácidos grasos. Rev. Colomb. Cienc. Pecu. 2010, 23, 308-316.

10. Prieto-Guevara, M.; Atencio-García, V. Zooplancton en la larvicultura de peces neotropicales. [Zooplankton in larviculture of neotropical fishes.]. Rev. Med. Vet. Zootec. Córdoba 2008, 13, 1415-1425. [CrossRef]

11. Prieto-Guevara, M.; De la Cruz, L.; Morales, M. Cultivo experimental del cladocero Moina sp alimentado con Ankistrodesmus sp y Saccharomyces cereviseae. Revista MVZ Córdoba 2006, 11, 705-714. [CrossRef]

12. Morales-Ventura, J.; Nandini, S.; Sarma, S.; Castellanos-Páez, M.E. Demography of zooplankton (Anuraeopsis fissa, Brachionus rubens and Moina macrocopa) fed Chlorella vulgaris and Scenedesmus acutus cultured on different media. Rev. Biol. Trop. 2012, 60, 955-965. [CrossRef]

13. Persson, J.; Vrede, T. Polyunsaturated fatty acids in zooplankton: Variation due to taxonomy and trophic position. Fresh Water Biol. 2006, 51, 887-900. [CrossRef]

14. Masclaux, H.; Bec, A.; Kainz, M.J.; Perriere, F.; Desvilettes, C.; Bourdier, G. Accumulation of polyunsaturated fatty acids by cladocerans: Effects of taxonomy, temperature and food. Fresh Water Biol. 2012, 57, 696-703. [CrossRef]

15. Hartwich, M.; Martin-Creuzburg, D.; Wacker, A. Seasonal changes in the accumulation of polyunsaturated fatty acids in zooplankton. J. Plankton Res. 2013, 35, 121-134. [CrossRef] 
16. Gama-Flores, J.L.; Huidobro-Salas, M.E.; Sarma, S.; Nandini, S.; Zepeda-Mejia, R.; Gulati, R.D. Temperature and age affect the life history characteristics and fatty acid profiles of Moina macrocopa (Cladocera). J. Therm. Biol. 2015, 53, 135-142. [CrossRef] [PubMed]

17. Abaho, I.; Bwanika, G.; Walekhwa, P.; Arinaitwe, A.V.I.; Kwetegyeka, J.S. Fatty acid profiles and growth of African catfish (Clarias gariepinus, Burchell, 1822) larvae fed on freshwater rotifer (s) and Artemia as live starter feeds. Int. J. Fish Aquat. Stud. 2016, 4 , 189-196. [CrossRef]

18. Das, P.; Mandal, S.C.; Bhagabati, S.; Akhtar, M.; Singh, S. Important live food organisms and their role in aquaculture. Front. Aquac. 2012, 5, 69-86. [CrossRef]

19. Mitra, G.; Mukhopadhyay, P.; Ayyappan, S. Biochemical composition of zooplankton community grown in freshwater earthen ponds: Nutritional implication in nursery rearing of fish larvae and early juveniles. Aquaculture 2007, 272, 346-360. [CrossRef]

20. Taghavi, D.; Farhadian, O.; Soofiani, N.M.; Keivany, Y. Effects of different light/dark regimes and algal food on growth, fecundity, ephippial induction and molting of freshwater cladoceran, Ceriodaphnia quadrangula. Aquaculture 2013, 410, 190-196. [CrossRef]

21. Nandini, S.; Alonso-Soto, R.; Sarma, S. Growth of Plankton (Scenedesmus acutus (Chlorophyceae) and Moina macracopa (Cladocera)) on domestic wastewater. CLEAN-Soil Air Water 2013, 41, 11-15. [CrossRef]

22. Kumar, S.; Srivastava, A.; Chakrabarti, R. Study of digestive proteinases and proteinase inhibitors of Daphnia carinata. Aquaculture 2005, 243, 367-372. [CrossRef]

23. Beerli, E.L.; Logato, P.V.R.; Freitas, R.T.F.d. Alimentação e comportamento de larvas de pacu, Piaractus mesopotamicus (Holmberg, 1887). Ciênc. Agrotecnol. 2004, 28, 149-155. [CrossRef]

24. David, C.; Lenis, G.; Castañeda, G.; Lopera, A.; Restrepo, L.F. La dieta usada en la primera alimentación afecta la ganancia de peso y longitud total de larvas de cachama blanca (Piaractus brachypomus). Rev. Colomb. Cienc. Pecu. 2011, 24, 48-53.

25. Menossi, O.C.C.; Takata, R.; Sánchez-Amaya, M.I.; Freitas, T.M.d.; Yúfera, M.; Portella, M.C. Crescimento e estruturas do sistema digestório de larvas de pacu alimentadas com dieta microencapsulada produzida experimentalmente. Rev. Bras. Zootec. 2012, 41, 1-10. [CrossRef]

26. Simhachalam, G.; Kumar, N.S.; Rao, K.G. Biochemical composition and nutritional value of Streptocephalus simplex as live feed in ornamental fish culture. J. Basic Appl. Zool. 2015, 72, 66-72. [CrossRef]

27. Sampaio, A.C.S. Desenvolvimento Inicial e Comportamento Alimentar da Matrinxã Brycon Amazonicus (GUNTHER, 1869), em Laboratório. Master's Thesis, Universidade Federal Do Rio Grande, Rio Grande, Brasil, 2010.

28. Tesser, M.B.; Portella, M.C. Ingestão de ração e comportamento de larvas de pacu em resposta a estímulos químicos e visuais. Rev. Bras. Zootec. 2006, 35, 1887-1892. [CrossRef]

29. Prieto-Guevara, M.J.; Logato, P.V.R.; Moraes, G.F.d.; Okamura, D.; Araújo, F.G.d. Tipo de alimento, sobrevivência e desempenho inicial de pós-larvas de pacu (Piaractus mesopotamicus). Cienc. Agrotecnol. 2006, 30, 1002-1007. [CrossRef]

30. Sars, G.O. Contributions to the Knowledge of the Fresh-water "Entomostraca" of South America, as Shown by Artificial Hatching from Dried Material. Arch. Mathemetik Natuwidenskab 1901, 23, 1-102.

31. AOAC International. Official methods of analysis of AOAC International, 21st ed.; AOAC International: Gaithersburg, MD, USA, 2019.

32. Hopkins, K.D. Reporting fish growth: A review of the basics 1. J. World Aquac. Soc. 1992, 23, 173-179. [CrossRef]

33. Sousa, F.D.R.; Elmoor-Loureiro, L.M.A. Cladóceros fitófilos (Crustacea, Branchiopoda) do Parque Nacional das Emas, estado de Goiás. Biota Neotrop. 2008, 8, 159-166. [CrossRef]

34. Diniz, L.P.; Elmoor-Loureiro, L.M.A.; Almeida, V.L.d.S.; Melo Júnior, M.d. Cladocera (Crustacea, Branchiopoda) of a temporary shallow pond in the Caatinga of Pernambuco, Brazil. Nauplius 2013, 21, 65-78. [CrossRef]

35. Kestemont, P.; Jourdan, S.; Houbart, M.; Mélard, C.; Paspatis, M.; Fontaine, P.; Cuvier, A.; Kentouri, M.; Baras, E. Size heterogeneity, cannibalism and competition in cultured predatory fish larvae: Biotic and abiotic influences. Aquaculture 2003, 227, 333-356. [CrossRef]

36. Acosta-Muñoz, A.H.; Ortega-Montenegro, C.; Sanguino-Ortiz, R.; Ceballos-Ruiz, B.L.; López-Macias, J.N. Evaluación de tres tipos de alimento como dieta en post-larvas de Sábalo Amazónico, Brycon melanopterus, (Cope, 1872). Vet. Zootec. 2010, 4, 42-50.

37. Prieto-Guevara, M.; Hernández, J.; Gómez, C.; Pardo, S.; Atencio-Garcia, V.; Rosa, P.V. Efecto de tres tipos de presas vivas en la larvicultura de bagre blanco (Sorubim cuspicaudus). Rev. Med. Vet. Zootec. Córdoba 2013, 18, 3790-3798. [CrossRef]

38. Barton, B.A.J. Stress in fishes: A diversity of responses with particular reference to changes in circulating corticosteroids. Integr. Comp. Biol. 2002, 42, 517-525. [CrossRef]

39. Hori, T.S.; Avilez, I.M.; Iwama, G.K.; Johnson, S.C.; Moraes, G.; Afonso, L.O.J. Impairment of the stress response in matrinxã juveniles (Brycon amazonicus) exposed to low concentrations of phenol. Comp. Biochem. Physiol. Part C Toxicol. Pharmacol. 2008, 147, 416-423. [CrossRef] [PubMed]

40. Ribeiro, F.F.; Qin, J. Prey size selection and cannibalistic behaviour of juvenile barramundi Lates calcarifer. J. Fish Biol. 2015, 86, 1549-1566. [CrossRef] [PubMed]

41. Ramírez-Merlano, J.A.; Otero-Paternina, A.M.; Corredor-Santamaría, W.; Medina-Robles, V.M.; Cruz-Casallas, P.E.; VelascoSantamaría, Y.M. Utilización de organismos vivos como primera alimentación de larvas de yaque (Leiarius marmoratus) bajo condiciones de laboratorio. Orinoquia 2010, 14, 45-58.

42. Janakiraman, A.; Altaff, K. Koi carp (Cyprinus carpio) larval rearing with different zooplankton live feeds to evaluate their suitability and growth performance. Int. J. Res. Fish. Aquac. 2014, 4, 181-185. 
43. Giacomini, H.C.; Shuter, B.J.; Lester, N.P. Predator bioenergetics and the prey size spectrum: Do foraging costs determine fish production? J. Theor. Biol. 2013, 332, 249-260. [CrossRef]

44. Iles, A.C.; Rasmussen, J.B.J.F.B. Indirect effects of metal contamination on energetics of yellow perch (Perca flavescens) resulting from food web simplification. Fresh Water Biol. 2005, 50, 976-992. [CrossRef]

45. Kaufman, S.D.; Gunn, J.M.; Morgan, G.E.; Couture, P. Muscle enzymes reveal walleye (Sander vitreus) are less active when larger prey (cisco, Coregonus artedi) are present. Can. J. Fish. Aquat. Sci. 2006, 63, 970-979. [CrossRef]

46. Luna-Figueroa, J.; Vargas, Z.d.J.; Figueroa, T. Alimento vivo como alternativa en la dieta de larvas y juveniles de Pterophyllum scalare (Lichtenstein, 1823). Av. Investig. Agropecu. 2010, 14, 63-72.

47. Aya, F.A.; Corpuz, M.; Garcia, L. Diet composition, feed preferences and mouth morphology of early stage silver therapon (Leiopotherapon plumbeus, K ner 1864) larvae reared in outdoor tanks. J. Appl. Ichthyol. 2015, 31, 77-82. [CrossRef]

48. Islam, M.; Hassan, M.; Begum, M.; Punom, N.; Begum, M.; Sultana, N.; Rahman, M. Effects of feeding zooplankton, Moina macrocopa (Straus, 1820) on the growth of Nile tilapia Oreochromis niloticus L. Bangladesh J. Sci. Ind. Res. 2017, 52, 81-88. [CrossRef]

49. Das, S.K.; Tiwari, V.; Venkateshwarlu, G.; Reddy, A.; Parhi, J.; Sharma, P.; Chettri, J. Growth, survival and fatty acid composition of Macrobrachium rosenbergii (de Man, 1879) post larvae fed HUFA-enriched Moina micrura. Aquaculture 2007, 269, 464-475. [CrossRef]

50. Rivera-Narváez, C.M.; Botero-Aguirre, M. Alimento vivo enriquecido con ácidos grasos para el desarrollo larvario de peces. Rev. Colomb. Cienc. Pecu. 2009, 22, 607-618.

51. Botero, M. Comportamiento de los peces en la búsqueda y la captura del alimento. Rev. Colomb. Cienc. Pecu. 2004, 17, 63-75.

52. Vandewalle, P.; Germeau, G.; Besancenet, P.; Parmentier, E.; Baras, E. Early development of the head skeleton in Brycon moorei (Pisces, Ostariophysi, Characidae). J. Fish Biol. 2005, 66, 996-1024. [CrossRef]

53. Leonardo, A.F.G.; Hoshiba, M.A.; Senhorini, J.A.; Urbinati, E.C. Canibalismo em larvas de matrinxã, Brycon cephalus, após imersão dos ovos à diferentes concentrações de triiodotironina $\left(\mathrm{T}_{3}\right)$. Boletim Inst. Pesca São Paulo 2018, 34, 231-239.

54. Maciel, C.M.R.R.; Lanna, E.A.T.; Maciel Junior, A.; Donzele, J.L.; Neves, C.A.; Menin, E. Morphological and behavioral development of the piracanjuba larvae. Rev. Bras. Zootec. 2010, 39, 961-970. [CrossRef]

55. Neumann, E. Desenvolvimento inicial de jatuarana, Brycon amazonicus (Teleostei, Characidae). Ph.D. Thesis, Universidade Estadual Paulista, Sao Paulo, Brasil, 2008. 